Res. Popul. Ecol. (1992) 34, $203-211$.

(C) by the Society of Population Ecology

\title{
DIFFERENTIAL DIET BREADTHS AND SPECIES COEXISTENCE IN LEAFROLLER-HUNTING EUMENID WASPS ${ }^{1}$
}

\author{
Takao ITINo \\ Laboratory of Applied Entomology, Faculty of Agriculture, Kagawa University, Miki-tyo, \\ Kita-gun, Kagawa 761-07, Japan
}

\section{SUMMARY}

There are, at least, three possible ways in which similar species coexist; resource partitioning, interference competition, and exploitation competition. Here, I investigated which way contributed to the coexistence of leafroller-hunting eumenid wasp species. Resource partitioning and, in addition, differential diet breadths proved to promote species coexistence in this case.

First, I analyze the prey records and diet overlap of four eumenid species in a local area. The larger two eumenids hunted similar-sized prey items and had similar potential taxonomic prey uses. But the diet breadth of the subsocial eumenid was much wider than that of the solitary one. As a result, the diet overlap between the two large eumenids decreased. This was because the solitary eumenid attend repeatedly to the same hunting site inhabited by one abundant prey species, while the subsocial one made random hunting. On the other hand, the two medium-sized eumenids partitioned resources according to prey size.

Secondly, I related these results to prey choice by several other species of eumenid obtained from literature sources. Ten Japanese common eumenids were divided into four groups according to their prey size. In each of the four groups, 2 to 3 wasp species differentiated the habitat ( 1 group) or coexisted by means of differential diet breadths (parallel with differential sociality, 2 groups).

Keywords: coexistence, diet breadth, resource partitioning, Eumenidae, prey records, sociality.

\section{INTRODUCTION}

Studies of competition and community structure revealed that there are, at least, three ways in which similar species coexist. 1. Species partition the spectrum of available resources and habitats (e.g., MacArthur and Levins, 1967; May and MacArthurr, 1972; Pulliam, 1975; Werner, 1977), 2. Species compete for the same resource by means of direct interference (e.g., Hutchinson and MacArthur, 1959; 
Miller, 1967; Johnson and Hubbell, 1974), and 3. Species compete exploitatively for the same resource (e.g., Davidson, 1977; Schaffer et al., 1979). Here, four species of eumenid wasps coexisted in part by means of resource partitioning according to the prey size (1) and partly by means of differential diet breadths resulted by respective foraging strategies. The latter case is regarded as resource partitioning (1) and/or exploitative competition for the same resource (3).

The Eumenidae are all predators, hunting lepidopterous or coleopterous larvae for their young (Iwata, 1976). In Japan, 17 genera and 54 species are currently recognized, most of which hunt leaf-rolling or leaf-mining lepidoperous larvae (Yamane, 1990). The diet of each species is restricted to one to several lepidopterous families. The diet breadth of each eumenid wasp species is wider than that of sphecid hunting solitary wasps and narrower than that of vespid social wasps (Iwata, 1976).

In a four year study on the community organization of tube-renting wasps in Kyoto (central Japan), a total of at least 6 leafroller-hunting eumenids coexist within a local area $(8 \times 8 \mathrm{~km})$. Here I analyze mechanisms of coexistence in the leafrollerhunting eumenids in order to assess the interactions which determine the organization of this community, and then compare the results to prey choice of several Japanese common eumenid species obtained from literature sources.

\section{Materials AND Methods}

Censuses were made within a $2 \times 2 \mathrm{~km}$ range in the northern suburbs of Kyoto, central Japan (alt. $200 \mathrm{~m}$ ). The area contains paddy fields, deciduous forests, and artificial coniferous forests. About 50 small sheds are scattered all around the study area, each containing 40-100 bamboo poles (inner diameter $>2 \mathrm{~cm}$ ) that have been maintained by farmers for more than 30 years. The cut ends of the poles were available nest sites for Orancistrocerus drewseni. I added 50-100 bamboo internodes (inner diameter $<2 \mathrm{~cm}$ ) at each of about 30 sheds. The cut ends of the internodes were available for all the four eumenid species. The study sheds were separated from each other by at least $50 \mathrm{~m}$.

I checked 42 and 19 sheds weekly during June-October of 1981 and 1982, respectively, collected the completed wasp nests, and dissected them to identify the wasp species and to get the data on their prey items. Each prey item was identified to genera, subfamily or family and was given a species number.

The sizes (female's mean forewing length) and provisioning methods of the four eumenids were as follows. $O$. drewseni: $13.3 \mathrm{~mm}$ and progressive provisioning (identical to subsocial form; feeding of larvae at intervals during their growth), Anterhynchium flavomarginatum: $13.3 \mathrm{~mm}$ and mass provisioning (solitary form; the method of feeding larvae in which food for the entire larval growth is enclosed in a cell which is ordinarily not opened until emergence of the young adult), Discoelius japonicus: $11.8 \mathrm{~mm}$ and mass or (on occasions) progressive provisioning, Euodynerus dantici: 
$10.8 \mathrm{~mm}$ and mass provisioning. Their nesting biology is best referred to Iwata (1976).

\section{Results}

Prey records of the four eumenids represent their taxonomic prey use and diet breadths (Table 1). Taxonomically, 0 . drewseni females hunted caterpillars of 72 species out of 5 families. Although $A$. flavomarginatum females primarily took larvae of Pyralidae, especially those belonging subfamilies Pyraustinae and Phycitinae, they occasionally hunted larvae of other taxa. D. japonicus also preyed upon several taxa while $E$. dantici concentrated on one species of Pyralidae. At other locality, females of $E$. dantici hunt larvae of Gelechiidae in large number (Iwata, 1980). These facts may suggest that the taxonomic categories of prey species are not so different among wasp species. Similar to other solitary or subsocial wasps with advanced flexible behavior, eumenid wasps have high plasticity of prey choice allowing them to have wider taxonomic ranges of prey items (Iwata, 1976).

Comparison of the diet breadth $(H)$ among wasp species (Table 1 ) confirm that those preying upon more species have wider diet breadth. This, coupled with their similar taxonomic prey use, may imply that the differential diet breadths are caused by

Table 1. Total subfamilial or familial prey records for species of Eumenidae. $N S=$ number of species; $N=$ number of individuals, $H=-\Sigma p_{i} \log p_{i}$ where $p_{i}$ are the proportions of the total prey items belonging to the ith prey species.

\begin{tabular}{|c|c|c|c|c|c|c|c|c|}
\hline \multirow{2}{*}{ Prey taxa } & \multicolumn{2}{|c|}{ O. drewseni } & \multicolumn{2}{|c|}{ A. flavomarginatum } & \multicolumn{2}{|c|}{ D. japonicus } & \multicolumn{2}{|c|}{$E$. dantici } \\
\hline & $N S$ & $N$ & $N S$ & $N$ & $N S$ & $N$ & $N S$ & $N$ \\
\hline \multicolumn{9}{|l|}{ Pyralidae } \\
\hline Phycitinae & 22 & 730 & 2 & 258 & 1 & 1 & & \\
\hline Pyraustinae & 10 & 246 & 20 & 816 & 1 & 25 & 1 & 478 \\
\hline Pyralinae & 7 & 265 & & & & & & \\
\hline Epipaschiinae & 6 & 152 & 1 & 1 & 1 & 2 & & \\
\hline Schoenobiinae & 1 & 11 & & & & & & \\
\hline unknown & 6 & 8 & & & & & & \\
\hline Tortricidae & 11 & 143 & 3 & 6 & & & & \\
\hline Noctuidae & 4 & 58 & 1 & 54 & 1 & 18 & & \\
\hline Gelechiidae & 1 & 1 & & & & & & \\
\hline Geometridae & 1 & 1 & & & & & & \\
\hline unknown & 3 & 7 & & & & & & \\
\hline \multicolumn{9}{|l|}{ Total number of } \\
\hline Families & \multicolumn{2}{|c|}{5} & \multicolumn{2}{|c|}{3} & \multicolumn{2}{|c|}{2} & \multicolumn{2}{|c|}{1} \\
\hline Species & \multicolumn{2}{|c|}{72} & \multicolumn{2}{|c|}{27} & \multicolumn{2}{|c|}{4} & \multicolumn{2}{|c|}{1} \\
\hline Individuals & \multicolumn{2}{|c|}{1622} & \multicolumn{2}{|c|}{1135} & \multicolumn{2}{|c|}{46} & \multicolumn{2}{|c|}{478} \\
\hline \multicolumn{9}{|l|}{ Diet breadth $(H)$} \\
\hline 1981 & \multicolumn{2}{|c|}{1.15} & \multicolumn{2}{|c|}{0.93} & \multicolumn{2}{|c|}{0.40} & \multicolumn{2}{|c|}{0.00} \\
\hline 1982 & \multicolumn{2}{|c|}{0.99} & \multicolumn{2}{|c|}{0.50} & \multicolumn{2}{|c|}{-} & \multicolumn{2}{|c|}{-} \\
\hline
\end{tabular}


Table 2. Diet overlap between $O$. drewseni $(O), A$. flavomarginatum $(A)$ and $D$. japonicus $(D)$. Numbers in parentheses indicate the percentages to total numbers of prey items.

\begin{tabular}{|c|c|c|c|c|}
\hline \multirow{2}{*}{ Combination of wasps } & \multirow{2}{*}{$\begin{array}{c}\text { No. of } \\
\text { prey species }\end{array}$} & \multicolumn{3}{|c|}{ No. hunted by: } \\
\hline & & O. drewseni & A. flavomarginatum & D. japonicus \\
\hline$O \times A \times D$ & 1 & $159 \quad(9.8)$ & $27 \quad(2.4)$ & $1 \quad(2.2)$ \\
\hline$O \times A$ & 9 & $173 \quad(10.7)$ & $600 \quad(52.9)$ & \\
\hline$O \times D$ & 1 & $119 \quad(7.3)$ & & $2 \quad(4,4)$ \\
\hline$O$ & 61 & $1171 \quad(72.2)$ & & \\
\hline$A$ & 17 & & $508 \quad(44.8)$ & \\
\hline$D$ & 2 & & & $43 \quad(93.5)$ \\
\hline Total & & $1622(100.0)$ & $1135(100.0)$ & $46(100.0)$ \\
\hline
\end{tabular}

interspecific differences in foraging strategy, i.e., whether exploiting several major prey species repeatedly or hunting those they happened to find during random searchings. For example, E. dantici females appeared to exploit one abundant prey species within their foraging area. They have also been reported to take one prey species intensively and repeatedly at one site in each of two districts of Japan, where they preyed upon other species than this study (Iwata, 1938, 1980). Females of $A$. flavomarginatum were observed to attend repeatedly to the same hunting site inhabited by one abundant prey species. On the other hand, in $O$. drewseni, the consecutive hunting of the same prey species were less often observed (Itino, personal observation).

The hypothesis that each wasp's foraging strategy delimits its taxonomic prey utilization pattern and then promotes the resource allocation and species coexistence, is also evidenced in analyses of the diet overlap. The taxonomic prey use overlapped between $O$. drewseni and $A$. flavomarginatum (Table 2). Note that their body size and prey size were about the same while those of $D$. japonicus were smaller and those of $E$. dantici much smaller (see Discussion). Ten prey species common to $O$. drewsen $i$ and A. flavomarginatum account for 20.5\% (332 individuals), and 55.2\% (627 individuals) of their total prey items, respectively. Since the 10 species account for only $14.0 \%$ and $37.0 \%$ of the total number of prey species in $O$. drewseni and A. flavomarginatum, respectively, the 10 common prey species are identified, on a individual species basis, to be hunted more frequently than the other prey species. This suggests that the two wasp species both exploit the abundant common 10 prey species intensively in their searching area (shrubs or stands of deciduous trees), but the intensities are different between wasp species according to the respective foraging strategies. In such a way, they partitioned the resources or minimized the niche overlap. If they utilized the same foraging strategies, the diet overlap would be enlarged and exploitative competition would be more severe.

The smaller diet overlaps between the larger two eumenids $(O$. drewseni and A. flavomarginatum) and $D$. japonicus and between they and $E$. dantici were the consequences of the differential prey size (see Discussion). 


\section{Discussion}

The preceding results suggest that interspecific differences in diet breadth play a significant role in the coexistence of $O$. drewseni and $A$. flavomarginatum. The diet breadth $(H)$ of $O$. drewseni was much wider than that of the similar-sized eumenid $A$. flavomarginatum although their potential taxonomic prey uses were similar (so, it is not the case of specialist-generalist continuum). This contributes to the smaller diet overlap and appears to enable them to coexist. The other two eumenids, $D$. japonicus and $E$. dantici, partition resources by means of a shift of prey size (Table 3 ).

It is of interest to consider the community structure of eumenids in a broader perspective. Table 3 lists 10 common species of Japanese leafroller-hunting Eumenidae for which wasp body size (FL), taxonomic category of prey items (PI), relative prey size to the wasp body size (indicated by number of prey items per young: PPY), nesting season, social form, and miscellaneous information are shown. The data and the following statements are from the literature (Iwata, 1975, 1979, 1980; Yamane, 1990) and the author's unpublished records to be given elsewhere. Ten wasp species are clearly divided into four groups according to their prey size (Table 3 ). The three large wasp species prey upon large prey items (about $2 \mathrm{~cm}$ in body length) although Rhynchium quinquecinctum are believed to have invaded Japan recently (Iwata, 1975) and take extra-large prey items $(2-3 \mathrm{~cm})$. The four medium-sized eumenids are divided into two groups according to much different value of PPY. $E$. nipanicus and $D$. japonicus prey upon medium-sized caterpillars $(1-2 \mathrm{~cm})$ while $E$. dantici and Pararrhynchium ornatum prey upon small-sized caterpillars (about $1 \mathrm{~cm}$ ). Since the smallest Stenodynerus spp. had been confused under the name frauenfeldi until Yamane's taxonomic revision (1990), their biological characters are combined in Table 3. They prey upon extra-small larvae of leaf-rollers and even leaf-miners (about $5 \mathrm{~mm}$ ).

Here, we can detect at least two kinds of pattern in the community structure of eumenid wasps. First, among the four categorized groups, wasps partition resources according to prey size. Second, in each of the four groups, 2 to 3 wasp species coexist regardless of their similar preferences of prey size and taxonomic category of prey. In each of the first (excluding $R$. quinquecinctum) and third groups, the two coexisting wasp species differ in their social form, i.e., solitary and subsocial. As indicated in the Results, the solitary and subsocial forms are consistent with narrow and wide realized diet breadth, respectively, at least in the case of the four eumenid species studied here. This proved to also be the case in the subsocial wasp, $P$. ornatum (Itino personal observation, Iwata, 1975). So, the species coexistences in the first and third groups appear to be maintained by the differential diet breadth. In the second group, the two species seldom coexist because of their differential altitudinal preferences. The mechanism of coexistence in the fourth group (three species of Stenodynerus) is to be investigated. 
Table 3. Biological characters of 10 Japanese leaf-roller hunting eumenid wasps commonly distributed in Honsyu Island. FL = mean female forewing length (mm); PI = familial composition of prey items; $\mathrm{P}=$ Pyralidae; $\mathrm{T}=$ Tortricidae; $\mathrm{GR}=$ Gracillariidae; $\mathrm{GE}=$ Gelechiidae; $\mathrm{L}=$ Lyonetiidae; $\mathrm{PPY}=$ mean no. of prey items fed per young; $\mathrm{s}=$ solitary; sub=subsocial.

\begin{tabular}{|c|c|c|c|c|c|c|}
\hline Wasp species & FL. & PI & PPY & $\begin{array}{l}\text { Active season of } \\
\text { nesting females }\end{array}$ & Sociality & Note \\
\hline Rhynchium quinquecinctum & 14.3 & $\mathrm{P}$ & 7 & July-Sep & $\mathrm{s}$ & sporadic distribution \\
\hline A. flavomarginatum & 13.3 & $\mathrm{P}, \mathrm{T}$ & 12 & July-Oct & $\mathbf{s}$ & \\
\hline O. drewseni & 13.3 & $P, T$ & 13 & June-Oct & sub & \\
\hline Euodynerus nipanicus & 10.0 & $\mathrm{~T}, \mathrm{P}$ & 5 & June-Sep & s & plain region \\
\hline D. japonicus & 11.8 & $\mathrm{P}, \mathrm{T}$ & 5 & May-Sep & s or sub & mountain region \\
\hline E. dantici & 10.8 & GE, $P$ & 29 & July-August & s & \\
\hline Patarrhynchium ornatum & 11.5 & GR, GE, T & 25 & June-Oct & sub & \\
\hline Stenodynerus frauenfeldi & 6.8 & & & June-Sep & unknown & \\
\hline$S$. chinensis & 6.8 & $\mathrm{~L}, \mathrm{GR}, \mathrm{GE}$ & 45 & June-Sep & unknown & \\
\hline S. tokyanus & 7.5 & & & July-Oct & unknown & \\
\hline
\end{tabular}

Table 3 collectively suggests that, first, eumenids partition resources according to prey size, and second, species which have similar prey-size preferences can coexist if they differ in the social form or in their habitats.

Evans (1970) showed that, within a sphecid wasp community, the wasps appeared to partition the available prey, and when similar prey are used, differences in seasonality or nesting substrata usually occur. Similar results are documented by O'Neill and Evans (1982) who described patterns of prey use in Philanthus wasp species (Sphecidae). The present study indicates another mechanism for the coexistence of similar wasp species, i.e., differential diet breadths resulted by different foraging strategies.

Such a mechanism of coexistence was first suggested by Johnson and Hubbell (1975), who analyzed coexistence of group and individually foraging bees. They demonstrated that the group foraging bee, Trigona fuscipennis, specialized on clumps of Cassia flowers, while an individual forager, $T$. fulviventris, exploited primarily spatially dispersed flowers of the same shrub species. They indicated that such a separation of feeding grounds promote coexistence of the bees and proposed the terms "high- and low-density specialists" to describe such species. A similar case of species coexistence was indicated by Davidson (1977) who studied desert seed-eating ant communities containing group and individually foraging species. Schaffer et al. (1979), who analyzed the exploitative competition among three bee species visiting Agave flowers, demonstrated further evidence in which coexistence of similar species is maintained by the density specialization. In the present study, wasp species with narrow and wide diet breadth correspond to the high- and low-density specialist, respectively.

More generally, all of these cases are examples of what Miller (1967) has called the included-niche phenomenon, i.e., where the fundamental niche of one species is 
totally included within that of another, but where the first species can outcompete the other in its part of the niche space. With respect to the eumenid wasps, the fundamental niche of the narrow diet breadth species was, on a taxonomic category basis, similar to that of the wide diet breadth species, but, on a high- or low- density basis, may be included within the fundamental niche of the wide diet breadth species.

Johnson and Hubbell (1975) suggested the separation of feeding grounds by the bees was maintained in part by $T$. fuscipennis actively excluding $T$. fulviventris from the densest flower patches and in part by evolved differences in density specialization between group and individual foragers. On the other hand, Schaffer et al. (1979) demonstrated that exploitative competition between the bee species was the very mechanism maintaining the separation of foraging grounds. In eumenids, evolved differences in density specialization and exploitative competition may be the mechanisms, in part because $O$. drewseni took diverse prey species even in the absence of $A$. flavomarginatum which suggest its restricted foraging pattern, and in part because no direct interferences between eumenid species for the same resource were observed.

The matching of solitary-subsocial form and narrow-wide diet breadth suggests that social form has some effects on the foraging strategy. Solitary wasp females feed their young as fast as possible because their fitness appears to increase linearly as the feeding velocity increases, which is not the case in subsocial wasps (Itino, 1986, 1988). So, they evolved expensive adaptations for exploiting high density resources that make foraging economically unprofitable under other resource regimes. Subsocial wasps, on the contrary, have preadaptations for the slower feeding velocity, which enables them to make shift with low density resources.

Acknowledgenents: I am indebted to Dr. Y. Yoshiyasu for identifying the lepidopterous larvae. Dr. T. Inoue generously provided helpful counsel and stimulating discussion throughout the study. This research was partly supported by a Grant-in-Aid No. 63760046 from the Japan Ministry of Education, Science and Culture.

\section{REFERENCES}

Davidson, D. W. (1977) Foraging ecology and community organization in desert seed-eating ants. Ecology 58: 725-737.

Evans, H. E. (1970) Ecological-behavioral studies of the wasps of Jackson Hole, Wyoming. Bull. Mus. Comp. Zool. 140: 451-511.

Hutchinson, G. E., and R. H. MacArthur. (1959) On the theoretical significance of aggressive neglect in intraspecific competition. Amer. Natur. 93: 133-134.

Itino, T. (1986) Comparison of life tables between the solitary eumenid wasp Anterhynchium flavomarginatum and the subsocial eumenid wasp Orancistrocerus drewseni to evaluate the adaptive significance of maternal care. Res. Popul. Ecol. 28: 185-199.

Itino, T. (1988) The spatial patterns of parasitism of eumenid wasps, Anterhynchium flavomarginatum and Orancistrocerus drewseni by the miltogrammine fly Amobia distorta. Res. Popul. Ecol. 30: 1-12.

Iwata, K. (1938) Habits of eight species of Eumenidae (Rhynchium, Lionotus, and Symmorphus) in Japan. Mushi 11: 110-132. 
Iwata, K. (1975) Field notes of a naturalist. Asahi-sinbun-sya, Tokyo, Japan. (In Japanese)

Iwata, K. (1976) Evolution of instinct: comparative ethology of Hymenoptera. Amerind Publishing Company, New Delhi, India.

Iwata, K. (1979) Fifty year field notes of an entomologist. Vol. 3. Asahi-sinbun-sya, Tokyo, Japan. (In Japanese)

Iwata, K. (1980) Fifty year field notes of an entomologist. Vol. 4. Asahi-sinbun-sya, Tokyo, Japan. (In Japanese)

Johnson, L. K., and S. P. Hubbell. (1974) Aggression and competition among stingless bees: field studies. Ecology 55: 120-127.

Johnson, L. K. and S. P. Hubbell. (1975) Contrasting foraging strategies and coexistence of two bee species on a single resource. Ecology 56: 1398-1406.

MacArthur, R. H., and R. Levins. (1967) The limiting similarity, convergence, and divergence of coexisting species. Amer. Natur. 101: 377-385.

May, R. M., and R. H. MacArthur. (1972) Niche overlap as a function of environmental variability. Proc. Nall. Acad. Sci. U.S.A. 69: 1109-1113.

Miller, R. S. (1967) Pattern and process in competition. Adv. Ecol. Res. 4: 1-74.

O'Neill, K. M. and H. E. Evans. (1982) Patterns of prey use in four sympatric species of Philanthus (Hymenoptera: Sphecidae) with a review of prey selection in the genus. Journal of Natural History 16: 791-801.

Pulliam, R. H. (1975) Coexistence of sparrows: a test of community theory. Science 189: 474-476.

Schaffer, W. M., D. B. Jensen, D. E. Hobbs, J. Gurevitch, J. R. Todd and M. V. Schaffer. (1979) Competition, foraging energetics, and the cost of sociality in three species of bees. Ecology 60: 976987.

Werner, E. E. (1977) Species packing and niche complementarity in three sunfishes. Amer. Natur. 111: 553-578.

Yamane, Sk. (1990) A revision of the Japanese Eumenidae (Hymenoptera, Vespoidea). Insecta Matsumurana New Series 43: 1-189. 
葉巻蛾を狩るドロバチ類における餌選択幅の相違と種の共存

\section{市 野 隆 雄}

自然界における近似種の共存様式としては，資源分割，干渉型の競争，および先取り型の競争な どが知られている、メイガ科やハマキガ科などの葉巻蛾を狩るドロバチ類の共存様式について，資 源分割とともに慨種選択幅の広狭が種の共存をゆるす要因になっていることが示唆された.

まず, 野外におけるドロバチ類 4 種の慨種構成, および慨種選択の重複度について 2 年間のデー タから検討した. 大型の 2 種のドロバチは餌サイズと餌の分類群のいずれにおいても潜在的な選好 性は類似していたが，実際に狩ってくる慨種の構成は，亜社会性ドロバチが単独性ドロバチよりる 多様であった，この原因は，単独性種が主選好の餌種を集中的に狩るのに対し，亜社会性種は，ラ ンダム採餉を行なっていることによる.この結果, 両種ドロバチの餌種の重複度は低下していた。

一方，中型の 2 種のドロバチ同士は，餌サイズの選好性をちがえていた.

次に, 日本産の普通種のドロバチ 10 種について, 餌サイズ, 餌の分類群, 八チの社会性の程度な どを文献資料る用いて比較検討した．10種は慨サイズの違いによって4つのダループに分れた．各 グループ内の種同士を比較すると，生息場所が異なっている場合（1ダループ）とともに，生息場 所は類似しているが，餪種選択幅が異なり，かつ社会性の程度が異なっている場合（2グループ） が認められた（残りの1グループの共存機構は不明）. 以上より, 社会性の程度の差が採慨戦略和よ び餌選択幅の相違をらみ，ひいては種の共存をゆるす一つの機構となっている可能性が示唆された。 